Article

Axel Hilling*, Niklas Sandell, and Anders Vilhelmsson

\title{
Tax Planning in Partner-owned Close Corporations $^{\star *}$
}

https://doi.org/10.1515/ntaxj-2017-0008

Received Aug 28, 2017; accepted Sep 25, 2017

\section{Aggressive tax planning and tax policy}

Over the past years, the scholarly discussion on tax law has focused largely on aggressive tax planning (Dourado 2015; Panayi 2015). "Aggressive tax planning" is not a legal term; it refers primarily to transactions whereby companies take advantage of discrepancies-arbitrage-between tax laws of different countries, thereby achieving a more favorable taxation than the comparable taxpayers who have no access to such tax-planning opportunities. Aggressive tax planning, then, is not a matter of evading the law, but of exploiting, for purposes of personal gain, the limitations and shortcomings of the law with regard to certain transactions. Or, as Murphy (2005) defines it: "Aggressive tax planning by its very nature involves finding ways to accomplish compliance with the letter of the law while totally undermining the policy intent or spirit behind the legislation" (p. 563).

Tax planning, whereby tax arbitrages are exploited for personal gain, is not merely an issue within international taxation, however, it can also occur in domestic transactions. Differences in tax rates for different types of income

\footnotetext{
*Corresponding Author: Axel Hilling: Associate Professor of Business Law, Knut Wicksell Centre for Financial Studies, School of Economics and Management, Lund University, Lund, Sweden; Email: axel.hilling@har.lu.se

Niklas Sandell: Senior Lecturer of Business Administration, School of Economics and Management, Lund University, Lund, Sweden Anders Vilhelmsson: Associate Professor of Economics, Knut Wicksell Centre for Financial Studies, School of Economics and Management, Lund University, Lund, Sweden

$\star \star$ The authors thank the Ragnar Söderberg Foundation for the financial support needed to complete this article. Responsibility for all errors and omissions remains with the authors.
}

are often the result of tax policies aimed at stimulating economic growth and entrepreneurship through targeted tax benefits. When tax policy results in changes to the law with the aim of influencing the behavior of taxpayers, the practice of tax planning is being implicitly encouraged (Gribnau 2015; Freedman 2006). Tax benefits obtained by taking advantage of favorable taxation may be regarded as a reward for acting in line with the wishes of the legislator. Yet it may also be that the letter of the law is exploited in situations that were not intended by the legislator. Even if the legislator intended beneficial taxation, tax planning may result in taxation deemed excessively favorable, and thus unfair, by other taxpayers. This creates a tacit limit beyond which the tax benefits cannot be given without challenging the legitimacy of the tax system.

Tax policy may also be deemed illegitimate by some taxpayers because they perceive it as inefficient (Edin et al. 2005). Because business and entrepreneurship is a presupposition for long-term economic growth in any society, taxpayers engaged in private enterprise expect support in their endeavors by means of targeted, stimulating tax policies. This, too, creates a tacit limit for tax law-a minimum requisite level of tax policy intervention. Entrepreneurs will regard a tax system as illegitimate if they are subject to levels of taxation that are not significantly different from those of other taxpayers (Edin et al. 2005).

Accordingly, a good tax law is one that is regarded as legitimate by the public, while incentivizing certain groups to contribute to the economic growth through private entrepreneurship. Then generally, there is a delimited area to which tax law and policy must be confined in order to maintain legitimacy. If they venture beyond this "window of legitimacy" - through tax laws that are aimed at stimulating growth, but also enable tax planning to a degree considered unfair by the public-then either the law may be revised or its implementations may be tried in court. In this way, the system can retain its legitimacy over time.

The legislator and the Tax Agency share an overarching responsibility for securing the legitimacy of the tax system. This responsibility may be regarded as flowing from the Rule of Law, which establishes that taxes must be im- 
posed through a proper legal process, rather than through administrative or judicial discretion, and that the government and administration must comply with the laws that lawmakers have passed (Cooper 1997). In the government's decree to the Swedish Tax Agency, it is thus explicitly stated as a responsibility for the Agency to secure legality, consistency, and uniformity in the application of implemented tax legislation. ${ }^{1}$ Because the legitimacy of the tax system is fundamental to the society, strong demands can be made on the operations of the legislator and the Tax Agency. If these institutions fail to live up to the demands, their authority will be undermined, to the detriment of public confidence in and respect for the entire tax system. Not only can the taxpayers' actions threaten the legitimacy of this system, the actions of the legislator and the Tax Agency are also crucial for the citizens' trust in the tax system.

The purpose of this article is to expand the scholarly debate on legitimacy in tax law from a narrow focus on the behavior of taxpayers (e.g., aggressive tax planning) to include the responsibility of lawmakers and tax authorities for securing legitimacy. We make our contribution as a case study from the Swedish income taxation and take the changes to the taxation imposed on owners of close corporations from 2006 as our starting point. We also address the type of reward system used by some such owners, whereby shares are obtained without any capital investment and resold on the same terms-also known as nakedin, naked-out. Thus, more specifically, this article is about tax planning in partner-owned close corporations.

Our investigation is interdisciplinary and includes perspectives from both tax law and corporate finance. The empirical basis of the study is a close reading of the two judgments in the $p w c$ case $^{2}$, and all the available material presented to the court in that case. We read the material with an eye to understanding the arguments of the parties, the court's decision, and the parties' maneuvers during the trial. The material was interpreted in light of discussions in scholarly publications and in the business media regarding the expediency of the tax rules for close companies.

The body of the article is divided into five main sections. Section 2 explicates the notions of efficiency and legitimacy in tax law and the interrelationships between the two. Section 3 presents that Swedish tax law that was regarded as illegitimate in the case studied here. This is fol-

1 Paragraph 2, Förordning (2007:780) med instruktion för Skatteverket [Decree with instructions to the Tax Agency] (Swed).

2 Kammarrätten i Stockholm [Administrative Court of Appeal in Stockholm] Mål nr. 701-702-14, December 2014 (Swed). lowed in Section 4 by an account of the measures taken to resolve the problem of illegitimacy. The results of these efforts are assessed in Section 5, where some general conclusions are drawn.

\section{Tax policy, efficiency and legitimacy}

\subsection{Tax policy}

Taxes generally serve three societal functions: a fiscal function, a redistributive function, and a regulatory function (Avi-Yonah 2006). In most countries, these functions are ensured by different types of taxes-particularly by taxing consumption and income. As for which of these forms of taxation are best suited to fulfill the fiscal and redistributive functions, opinions diverge; but for the regulatory function, income tax seems clearly superior to consumption tax (Bankman and Weisbach 2006; Avi-Yonah 2006).

To begin with, income tax has a symbolic value. Public opinion can be addressed more effectively with directed interventions in income taxation than in consumer taxation. As a clear example, consider the last step in the Swedish progressive tax on labor income. It is regularly condemned as inefficient, even as an overall cost on society. Yet it remains in place as a symbol of the legislator's insistence that high earners pay their fair share of taxes (Öberg 2014), allowing policy makers to demonstrate their commitment to fairness.

Moreover, only a minor proportion of tax policy concerns consumption, although this proportion is likely to expand as the public grows increasingly concerned about environmental issues. Tax policy in the realm of business primarily addresses investments and savings (Avi-Yonah 2006). Regulation aimed at stimulating activity in this area must be directed at individuals' income rather than their consumption. Consequently, the income tax legislation abounds with regulation encouraging taxpayers to make investments for specific purposes, such as retirement or housing. Yet most tax laws serving regulatory functions concern corporations, in the form of generous deduction policies on investments in assets or generous taxation of proceeds from investments in private enterprise, demonstrating that efficiency and legitimacy must be balanced in the tax system. 


\subsection{Efficiency}

Income taxation is efficient insofar as it affects the taxpayer's behavior as little as possible (Hansson 2014). From an economic perspective, taxes are generally considered to be bringing about tax wedges, with a negative impact on behavior. Individuals are assumed to make rational choices-to act according to what will be most beneficial for their private financial situation or that of their company. To the extent that a tax influences this action, it introduces inefficiency into the economy, which, in turn, affects economic growth. From this viewpoint, taxation ought to be neutral and uniform, so as to have a minimal influence on behavior. This aspiration is clearly expressed in preparatory work to the laws of the current Swedish tax system. ${ }^{3}$ Nevertheless, as Arnold et al. (2011) have demonstrated, certain types of taxation have more adverse effects on economic growth than others do. In general, income taxation-especially corporate tax-is the most harmful to economic growth, and consumption and property taxes have the least adverse effects. Thus, there are loud calls for lowering or even abolishing corporate tax (Norrman and Virin 2007).

As far as taxes on individuals are concerned, some research shows that marginal taxes on personal income has a dampening effect on entrepreneurship and that a progressive income tax is negatively correlated with entrepreneurial risk-taking (Hansson 2010). Furthermore, the high mobility of capital brings the risk of losses in efficiency when capital is taxed (Soerensen 2010a,b). Taxing capital on the individual level thus inhibits economic growth, as Storey (1994) concluded upon finding a negative correlation between capital gains tax and entrepreneurship.

Furthermore, because the total tax revenues from the taxation of corporations and capital income distributed to corporate owners often amount to less than $10 \%$ of the total tax revenues of a government, tax benefits within this sector have a limited impact on the government's overall revenue raising. ${ }^{4}$ For this reason, and because of the adverse effects of such taxes on economic growth, they are often used as political instruments for furthering growth. The lowering of taxation on owners of close companies and unlisted companies in 2006 is one example; the lowering of the corporate tax over the past few years is an-

3 Regeringens Proposition [Prop.] 1989/90:110 om reformerad inkomsts- och företagsbeskattning [government bill] (Swed).

4 In 2014, the corporate tax revenues amounted to $8.8 \%$ of total tax revenues among OECD countries, OECD (2016), Revenue Statistics 2016, OECD Publishing. other. ${ }^{5}$ Because capital is more mobile than labor, taxes on work are less sensitive to international competition than the taxes on capital. This means that the introduction of types of tax policies mentioned here runs the risk of increasing the difference in effective tax between wage earners and capital owners. If this difference in taxation between capital and labor comes to be seen as excessive by a large number of wage earners, the legitimacy and even the fiscal function of the tax system is threatened.

\subsection{Legitimacy}

Tax systems cannot be considered merely from the point of view of marginal assumptions about the impact on efficiency by particular taxes or changes in tax laws. Most of us agree that taxes are necessary for the society to function well and to sustain democratic institutions (Murphy and Nagel 2002). The starting point for any discussion about taxes must therefore be a question of the size of public sector, which must then be financed as effectively as possible. The size of public sector, its financing by taxation, and specific taxes must all be perceived as legitimate.

In law, the concept of legitimacy encompasses the citizens' confidence in and convictions about the normative aptness of administrative structures, the actions and decisions of civil servants, and administrative processes. The legitimacy of rules and decisions depend, crucially, on who made them or how they came to be. Social science research offers several reasons why the rule of law in any society presupposes legitimacy. Legitimacy increases legal obedience and participation in elections, and facilitates the process of conducting political reforms (Tyler 1990). The legitimacy of tax law is ensured by good legislation and procedural justice, in which the ministries of finance and tax authorities play decisive roles. In addition, legitimacy encompasses normative questions about the fairness of law (Lodin 2007; Caldéron et al. 2016). This usage is justified, given that a fundamental aspiration of fairness in taxation pervades any tax system (Hemels 2015).

As mentioned, tax laws are often justified by reference to economic considerations, which often entail that a certain group of taxpayers is favored over another. This was the case in 1997, when a revision of the wealth tax exempted a dozen of the wealthiest persons in Sweden

5 Regeringens Proposition [Prop.] 2005/06:40, Reformerade beskattningsregler för ägare i fåmansföretag [government bill] (Swed); Statens Offentliga Utredningar [SOU] 2014:40, Neutral bolagsskatt för ökad effektivitet och stabilitet [government report series] (Swed). 
from this tax on a large portion of their wealth, as a strategy to reduce emigration of wealthy individuals (Henrekson 2017). Another example is the Swedish rule about selfcorrection, according to which the individuals who have withheld income from the Tax Agency may evade penalties, as long as they later report the income on their own initiative. Both cases are examples of legislation that give an exclusive advantage to one group, and of parliament justifying obviously unfair tax laws with reference to economic rationality.

Then there are examples in Sweden of obviously unfair tax legislation that is considered justified by economic considerations, demonstrating that equal treatment-fair taxation-cannot be used unconditionally as a measure of a law's virtue. It also indicates that legislation yielding tax benefits for a certain group of taxpayers need not be illegitimate, as long as there are convincing economic arguments for that discrimination. Economic rationality is a possible source of legitimacy, given a broad acceptance of the idea that discriminatory tax rules are preferable if they result in greater tax revenues than would rules that treat everyone equally. Thus, efficiency and legitimacy need not be conflicting goals, because effective taxes help secure a greater degree of social welfare-a consequence the public should be able to support. Yet reaching a point of balance between efficiency and legitimacy can be challenging for the legislator (Jagers and Hammar 2009). In some cases, the aims of efficiency and legitimacy will, at least in the short run and somewhat longer, pull in different directions.

Where, exactly, to draw the line between legally permissible transactions and transactions that constitute illegitimate tax planning is one of the perennial questions in the study of tax law, and it will not be pursued in this article. The example dealt with in the remainder of this article concerns legislation that clearly benefits a particular group of taxpayers, yet is clearly missing convincing economic arguments in favor of positive discrimination. This is the law enabling income shifting and tax arbitrage in close companies.

\section{Income shifting in close companies}

\subsection{Dual income taxation}

The Swedish tax system is premised on a comprehensive concept of income and explicit aspirations to impose taxes on a neutral and uniform basis-known as horizontal eq- uity. ${ }^{6}$ Like Norway and Finland, Sweden uses dual-income taxation, meaning that income from labor and capital are taxed separately (Soerensen 2010a,b). The system of dual taxation was originally designed to establish horizontal equity not only within each income category, but also between the two. An exception to this aim was introduced in order to make room for vertical equity in the form of progressive taxation of taxpayers with high incomes from labor. Similarly, because of the nominal taxation of capital income, an estimated inflation of approximately 4 percent at the beginning of the 1990s made the taxation of real capital income in line with vertical equity.

Since this system was introduced just over 25 years ago, significant changes have been made, ${ }^{7}$ resulting, for instance, in a growing gap between the tax rates on capital (which is exposed to international competition) and the tax on labor (which is less so). In 1990, relatively few individuals paid progressive tax on their work income, but that number had increased substantially by 2015. At the same time, taxes on capital have decreased substantially; corporate tax, for instance, has decreased to 22 percent from 30 percent. In addition, inflation is now steadily below 2 percent, rendering the taxation of real capital income considerably less burdensome compared to the situation that existed when the tax system was introduced and inflation was much higher, as the tax object is calculated on nominal bases.

One of the major reforms to have widened the gap between work and capital tax was the lowering (from 30 to 20 percent) of capital gains tax and dividends from shares in close companies. ${ }^{8}$ This reform was introduced in 2006 in hopes of boosting entrepreneurship and thereby increasing growth. It has since been extended through further legislation. The reform has led to a tax rate of approximately 38 percent on income from capital investments in close companies. The highest progressive tax on work, by contrast, is approximately 58 percent, not including payroll taxes, mandatory on all labor income. There is, therefore, a large tax wedge between the different types of income. The possibility of shifting income from labor to capital thus constitutes a significant case of tax arbitrage.

6 Statens Offentliga Utredningar [SOU] 1989:33, Reformerad inkomstbeskattning [government report series] (Swed).

7 Report to the Swedish National Audit Office RiR 2010:11, “Enhetlig Beskattning” 2010 (Swed).

8 Regeringens Proposition [Prop.] 2005/06:40, Reformerade beskattningsregler för ägare i fåmansföretag [government bill] (Swed). 


\subsection{Taxation of close companies}

The legal definition of a close company (regulated in Chapters 56 and 57 of the Swedish income tax act), including the definition of a qualified share in a close company, is detailed and complex. For the purpose of this article and in line with legal definitions in the income tax act, a close company is generally defined as a company in which the majority of voting rights are held by a limited number of individuals or their relatives, and in which these individuals or relatives also work for the company. Because of their majority of voting rights, in many situations these individuals may choose whether the surplus of the company shall be distributed to them as income from labor, in the form of wages, or as capital income in the form of dividends. Because the tax rates applicable to the two categories of income differ significantly, specific rules on the taxation of close companies are necessary for preventing the shifting of highly taxed labor income into capital income, with a lower applicable tax rate (Edin and Lodin 2008). These rules are generally referred to as the 3:12 rules, for the chapter and article number in the tax code where they were first introduced.

When the 3:12 rules were introduced, the greatest challenge was finding an appropriate way of dividing the returns of a company into the two types of income (Lodin 2009). The method that was settled upon was based on the value of the investment. It allowed a portion of the returns corresponding to a normal return to be taxed as capital gains. The normal return was initially determined by the government's borrowing rate, but this method has been revised numerous times. The current version dates to the 2006 reform, and bases the calculation of the possible amount to be taxed as capital income on the amount the company pays in salaries-the Salary rule. As mentioned, the tax rate on dividends and capital gains was also decreased from 30 to 20 percent. The legislator motivated the revision in the method of distinguishing capital from work income, with reference to concerns about legitimacy (Lodin 2009).

In work preparatory to the 2006 legislation, the law's legitimacy was taken to depend on it being perceived as legitimate, principally by the owners of close companies, but also by other social groups, especially wage earners (Lodin 2009). It was argued that a division based solely on the owner's capital investment lacked legitimacy in cases in which close companies have many employees. The owner ought to benefit from the value added to the company's return by its employees in the form of capital income, as is the case for companies not covered by the 3:12 rule (Edin and Lodin 2008). The concept of legitimacy is here understood as consisting of and confined to fairness among owners of different types of companies with regard to taxation. The Salary rule rests on the justification that, due to rules governing the labor market, the hiring of personnel involves greater risk, and that it appears unreasonable to conceive the greater part of the profit of a personnel-intensive company in terms of the owner's work contribution only-having it classified as the owner's wage.

As defined, the category of close companies includes not only family businesses; although in practice, such businesses constitute the majority of close companies. Companies with a relatively large number of employed shareholders-typically partner-owned firms-are also classified as close companies for income tax purposes. ${ }^{9}$ This extended definition seems necessary in order to prevent circumvention of the legislation, but also to take the edge off the 3:12 regulation as a policy instrument targeting small- and medium-sized entrepreneurs. Partners in large consulting firms benefit from the 3:12 regulation when they have their returns taxed as capital income, despite the fact that their capital investment might have been extremely limited or even nil. This situation has also drawn criticism to the 3:12 rules for favoring laborintensive companies with low profitability over capitalintensive companies with high profitability (Bjuggren and Johansson 2008).

\subsection{Room for income shifting within the framework of 3:12}

With a taxation that is not neutral between work and capital (3.1) and the 3:12 rules (3.2), the possibility of income shifting arises. Assuming a business income of 100 SEK in a close company before salaries and taxes, a payroll tax of 31 percent, a marginal work income tax of 55 percent, and a corporate tax of 22 percent, there is a tax wedge of 28 percentage points (about 9 percentage points if the marginal work income falls below the limit above which state income tax of 20 percent must be paid, see Table 1). It is significant, however, that the following example is relevant, particularly for an individual who earns above 40,000 SEK per month, because excess income from labor in that case will not grant any additional social benefits, such as pension, sickness compensation, and parental benefits, and

9 Regeringsrättens årsbok [RÅ] [Supreme Administrative Court Year Book] 1993 ref 99 (Swed). 
Table 1: Comparison of marginal income taxed as work income at $55 \%$, as work income at $30 \%$ and as capital income.

\begin{tabular}{|c|c|c|c|c|}
\hline & $\begin{array}{l}\text { Taxed as income } \\
\text { from work ( } 55 \% \\
\text { marginal tax) }\end{array}$ & $\begin{array}{l}\text { Taxed as income } \\
\text { from work ( } 30 \% \\
\text { marginal tax) }\end{array}$ & & $\begin{array}{l}\text { Taxed as income } \\
\text { from capital }\end{array}$ \\
\hline Business income & 100,0 SEK & 100,0 SEK & Business income & 100,0 SEK \\
\hline Payroll tax (31\%) & $-23,7$ SEK & $-23,7$ SEK & Corporate tax (22\%) & $-22,0$ SEK \\
\hline Marginal tax & $-42,0$ SEK & $-22,9$ SEK & $\begin{array}{c}\text { Tax on dividends } \\
(20 \%)\end{array}$ & $-15,6$ SEK \\
\hline Disposable income & 34,4 SEK & 53,4 SEK & Disposable income & 62,4 SEK \\
\hline $\operatorname{Tax}$ & 65,6 SEK & 46,6 SEK & $\operatorname{Tax}$ & 37,6 SEK \\
\hline $\begin{array}{l}\text { Tax as proportion of } \\
\text { income }\end{array}$ & $66 \%$ & $47 \%$ & $\begin{array}{l}\text { Tax as proportion of } \\
\text { income }\end{array}$ & $38 \%$ \\
\hline
\end{tabular}

the proportional payroll tax can thus be considered as an additional income tax.

The tax wedge between labor and capital income from close companies entails a strong incentive for owners to draw as large a share as possible from the companies' surplus as capital income. The greatest opportunity for the income shift arises in companies with high salary costs-in companies with many and amply paid employees. In such companies (e.g., partner-owned consulting businesses), the tax rules de facto result in highly taxed work income being shifted to capital income, with its lower tax rate.

\section{Legitimate or illegitimate tax planning?}

In the previous section, we demonstrated that the options for owners of close companies regarding the classification of their income as stemming from labor or capital, is clearly given to them by the legislation, and constitutes an intentional tax policy. In other words, the legislation embodies a tax policy whereby individuals are encouraged to run close companies and thereby contribute to greater entrepreneurship and growth, in exchange for a lower tax rate. As such, the policy invites the exercise of tax planning (running a close company). As it turned out, however, excessive use of income shifting in partner-owned closed companies-aimed at taking advantage of the tax incentives-turned out to be found illegitimate, and thus a key issue within the Swedish tax policy in the beginning of the 2010s. It all started with a newspaper article.

\subsection{The legitimacy and efficiency of tax planning}

\subsubsection{Public debates}

In the fall and winter of 2010-2011, a series of articles in Svenska Dagbladet, one of the most widely circulated and highly esteemed newspapers in Sweden, noted that partners in accounting firms often draw a large portion of their companies' surplus as dividends, which are taxed at a relatively low rate-all in accordance with the 2006 rules (Neurath and Bursell 2010). The articles also testify to widespread unawareness among ordinary taxpayers about the considerable tax reliefs available to accounting and consulting firms through the 3:12 rules. Within these articles, the Tax Agency attacked the accounting and consultancy business, arguing that the law does not permit the considerable tax reliefs enjoyed by that business (Bursell 2010a), while representatives from consultancy firms defended the favorable practice (Bursell 2010b). In the concluding article, Professor Sven-Olof Lodin, who helped draft the favorable rules, joined in the criticism of the tax planning in question and called for a revision to the law that would prevent it (Lodin 2011).

These articles implicitly question the legitimacy of tax rules that allow the partners of large accounting and consulting firms to enjoy considerable tax relief on income resulting from labor, rather than capital. The debate spread to other media and to the arena of national politics, driven by clear opposition to partners' tax reliefs (Zachrisson Winberg 2012). In its wake, the Tax Agency initiated a process of assessing whether the criticized arrangements could be reconciled with the law, and suggestions for other, stricter laws were presented in the media. Specialized forums also criticized the law and its generous tax reliefs for partners. 


\subsubsection{The Expert Group of Public Economics}

The Expert Group on Public Economics (ESO) is a committee attached to the Ministry of Finance; its task is to supply the legislator with the expertise and information needed to make economic and financial decisions. In a 2012 report, the ESO criticized the 3:12 rules of 2006 as excessively generous and as providing strong incentives to tax planning by means of income shifting (Alstadsæter and Jacob 2012a,b). Given laws that impose a 28-percentage point higher tax on income drawn as salary rather than dividends (by the tax rates of 2011), there is a clear incentive to shift incomes from salary to dividends (see Table 1). The study shows that labor incomes in close companies increased only marginally after the 2006 reform, whereas their capital income increased by more than 80 percent. In addition, statistics show that many individuals drawing dividends from close companies are high earners, meaning they are able to make use of the tax wedge. The study also noted that many of the close companies established after the 2006 reform are used solely for the purposes of income shifting. Alstadsæter and Jacob argue that the rules result in tax-adjusted transactions, which in turn lead to deadweight losses and thereby an unproductive use of resources. The study concludes that the regulation is less effective than it might have been, and that it is questionable on the basis of public economics.

Critics of Alstadsæter and Jacob's report say that its assessment of the 3:12 reform is not issued from a clearly defined normative stance (Ericson and Fall 2013). With reference to statements in preparatory works, to the effect that the law should seek to stimulate entrepreneurship, Ericson and Fall find the criticism of tax reliefs unfounded. They argue, in addition, that the empirical data presented in the ESO report is self-contradictory.

The fact that the 3:12 rules provide higher earners with incentives for tax planning is highlighted in yet another ESO report, from 2014 (Alstadsæter et al. 2014a). The authors of that report argue that although the 3:12 rules were conducive to investment, their impact on employment was negligible. In their view, it is unclear whether the value of the entrepreneurship created by the rules makes up for the income shifting for which they also pave the way (Alstadsæter et al.2014b). They also note that the type of tax planning the 3:12 rules give rise to may lack general acceptance among the public-may, in other words, undermine the legitimacy of the tax system.

The report provides several suggestions for ways in which the rules could be revised so as to limit the taxplanning leeway without decreasing the rules' positive effects on growth and entrepreneurship. First, companies with divided ownership, like consulting firms, should be excluded from the category of close companies and be categorized as unlisted companies instead. This would decrease the tax wedge by 5 percentage points. As employees of unlisted companies acquire shares therein, the difference between the subscription rate and the market value ought to be taxed as wages, and the market value should be determined by the standardized methods described in the finance and accounting literature (Alstadsæter et al. 2014b).

\subsubsection{Illegitimate and inefficient tax planning}

The public debate and criticism of the 3:12 rules in the 2012 ESO report indicate that the current rules fail at both legitimacy and economic efficiency. The rules have been presented as profoundly unfair, benefitting a small group of well-to-do partners (Hedelius 2013) and that they are inefficient in relation to the legislator's stated goals regarding entrepreneurship (Lodin 2011; Alstadsæter and Jacob 2012a,b). Combined, these criticisms mounted serious political pressure on the legislator to change the rules (Stenberg 2013). The Tax Agency responded by pursuing legal action against the accounting firm pwc, with the aim of trying the validity of the criticized type of tax planning. The Ministry of Finance took its own initiative and proposed new legislation. The next sections present and evaluate these responses.

\subsection{New legislation}

In the first half of 2013, the Ministry of Finance proposed a new piece of legislation. Massive criticism from both referral bodies and the Legal council (Lagrådet) yielded several suggestions. A revised version of the proposed law came into effect in 2014 (Hellekant and Hugo 2013). The new law is premised on the view that the leeway for salaries established by the 2006 rules is excessively generous for the partners of large firms with many partners and employees, thereby undermining the legitimacy of the rules. ${ }^{10}$ The new rules address the problem, principally by requiring that partners hold at least 4 percent of the shares of a company in order to be eligible for the salary-based leeway for calculating the portion of their income that will be taxed as

10 Regeringens Proposition [Prop.] 2013/14:1, Budgetproposition för 2014 [government bill] (Swed), 257. 
dividends (Ch. $57 \S 19 \mathrm{IL}^{11}$ ) - generally known as the capitalshare requirement. The law is based on statistics from a database, FRIDA, showing that 85 percent of partners in close companies with salary exceeding 250 million SEK shared less than 4 percent of the capital. In companies with salary less than 20 million SEK, only 2.5 percent had less than a 4 percent capital share. It was further noted that about 90 percent of partners owning less than 4 percent are in staff-intensive areas of business such as accounting and consulting firms, in which salaries are high.

The limitations introduced into the 3:12 rules subsequently met with heavy criticism for potentially inhibiting entrepreneurship and growth (Larsson and Sävenstrand 2013; Fall and Ericson 2013; Lodin 2014). Among the harshest critics is the Swedish Association of Lawyers (Sveriges Advokatsamfund 2013), which has argued that the rules do not serve to correct the problems identified by the legislator. Rather, companies prompted by the rules to change their operations may be affected negatively in relation to companies such as foreign competitors, to which the rules do not apply. ${ }^{12}$ Unjustified threshold effects may make the recruitment of important personnel more difficult. The association also faults the legislator for inadequacy in the prediction of consequences of the rules. A stern critic of the 2013 legislation, Tjernberg summarized the proposed law as follows:

Although I understand that the revision of the tax reform necessitates 3:12 rules, and with all due respect for any attempt to make the system legitimate and non-intimidating, I cannot but note that the 3:12 system has been derailed. Basic tax law requirements regarding neutrality, legal certainty and predictability have given way to political micromanagement and ad hoc solutions (Tjernberg 2013, 750).

A comprehensive report concerning the revisions of 3:12 was presented in November 2016, confirming much of the criticism that had been launched against the laws proposed in 2014 (Tjernberg 2017). ${ }^{13}$ The report also questioned whether a requirement for holding a minimum share of the company is compatible with the principles of neutrality and equality in taxation, and suggests that that

11 Regeringens Proposition [Prop.] 2013/14:1, Budgetproposition för 2014 [government bill] (Swed), 264.

12 Statens Offentliga Utredningar [SOU] 2016:75, Översyn av skattereglerna för delägare i fåmansföretag [government report series] (Swed), 178-82.

13 Statens Offentliga Utredningar [SOU] 2016:75, Översyn av skattereglerna för delägare i fåmansföretag [government report series] (Swed), 178-82. requirement be removed. ${ }^{14}$ The report also suggests that income shifting should be restricted on the basis of a more individualized salary calculation. New rules were slated to come into effect in 2018, but heavy criticism, and even political threats of motion of nonconfidence, had forced the government to withdraw its suggested rules by the end of August 2017. ${ }^{15}$. All that extensive work and engagement in new legislation had been for naught.

In a special opinion to the investigation, Lodin observed that the capital-share requirement missed its mark, and caused problems for smaller 3:12 companies (Lodin 2016). According to Lodin, the class of partner-owned firms that were the intended target of the requirement adjusted to the new regulation by restructuring. As such, their possibilities of income shifting were not lessened by the new rules. The same conclusion was confirmed in the decision of the Board for Advanced Ruling (Skatterättsnämnden) of 22 June $2016 .{ }^{16}$ Lodin suggests that a new formulation of the law require that employees' acquisitions of small company shares be taxed as part of their work income, insofar as the acquisition price is below 70 percent of the value of the share. Dividends from employees' shares, where rights of disposition are limited in such a way as to affect the value of the share, are to be taxed wholly as labor income. This latter part of Lodin's suggestion disqualifies dividends from shares acquired on a naked-in-naked-out basis from being taxed as capital income. As such, it should be effective in combatting the type of arrangements that the law of 2013 had hoped to target. The former part of Lodin's suggestion is based on the fundamental principle of today's tax system: that any valuable item given to employees by their employer without compensation from the employee be taxed as labor income. The value of shares acquired free of charge is determined by their market value. However, Lodin's suggestion does not seem to provide a solution to the problem of valuation that arises from a shareholder's option to choose whether surplus from the company is to be taxed as labor or capital income.

14 Statens Offentliga Utredningar [SOU] 2016:75, Översyn av skattereglerna för delägare i fåmansföretag [government report series] (Swed), 202.

15 Press release from Swedish Government: http://www.regeringen. se/artiklar/2017/08/forandringar-avseende-tre-remitteradeskatteforslag/, last visited 2017-09-19.

16 Skatterättsnämnden [SRN] [Board for Advanced Tax Ruling] SNR dnr 42-15/D, 22 June 2016 (Swed.); Högsta förvaltningsdomstolen [HFD] [Supreme Administrative Court] Mål nr 3826-16, 31 January 2017 (Swed). 
Given the considerable tax wedge between labor and capital income, the mere fact that a shareholder in a close company is free to decide whether dividends should be taxed as labor or capital confers a considerable value upon those shares. The same is not true of similar capital investments in companies not covered by the 3:12 rules. For this reason, it does not seem feasible to use the same template for assessing the value of shares in companies within and outside the 3:12 regulation, if the assessment is to be a reflection of the value the shareholder can expect to enjoy through the investment. The tax wedge and the option to have the return taxed as capital income make the prospective payoff of capital invested in a close company considerably greater than an equivalent investment made in an unlisted or public company.

Then, the question of valuation is particularly important and relatively complicated for income shifting on partners' shares. The Tax Agency had occasion to learn this during its attempt to combat the type of tax planning the partners of pwc engaged in using shares acquired on a naked-in-naked-out basis.

\subsection{The Tax Agency vs. pwc}

\subsubsection{The pwc ruling}

Around the time when the government demonstrated its commitment to fairness by introducing regulations against tax planning in partner-owned companies, the Tax Agency also decided to test whether the tax planning was compatible with current laws and regulations. As the pilot case, it chose the accounting firm pwc. In December 2012, it estimated higher payroll taxes for the company on the grounds that employees had acquired shares in the company at what was allegedly below market price. During the legal process, the Tax Agency argued that the tax relief that pwc partners had enjoyed through the company's partnership program should be taxed as a benefit. The case was first decided in the Administrative Court in Stockholm (Decision of 3 December 2013) and later in the Appeals Court (Decision of 12 December 2014). ${ }^{17}$ Both courts decided against the Tax Agency, because it had been unable to show that the value of the shares exceeded the price that pwc partners had paid.

The weak point of the Tax Agency's presentation of the case was the lack of plausible arguments in support

17 Kammarrätten i Stockholm [Administrative Court of Appeal in Stockholm] Mål nr. 701-702-14, December 2014 (Swed). of a different estimation between the value of partners' shares and the value cited by pwc. In our view, the Tax Agency's chances of success were slim, given the conditions set forth in the case. Eager to be seen as coming down hard on tax planning, the Tax Agency, like the Ministry of Finance, actually underperformed at its task. In the following sections, we provide an account of key factors in the case and explain the basis of our criticism.

\subsubsection{The value of partners' shares}

It is hard to find a clear-cut definition of a partner-owned company, but the essential characteristic seems to be that ownership is a means of collaboration and income distribution rather than acquisition of capital. ${ }^{18}$ This also means that the company's total results must be distributed among the partners, and that there must be a refusal clause forcing partners to sell back their shares at a predetermined time for the same price paid at the point of joining the partnership. In other words, partners should receive compensation only for their annual work and not earn capital gains by selling shares. Hence, the value of the shares is not directly determined by the business's surplus; nor, therefore, by the value of dividends. The shares do not yield a return on capital invested-indeed, in a naked-in-naked-out setup, there is no capital that can yield any return.

This means that the value of shares held by shareholding partners really exists in the value of possible tax benefit a shareholder can enjoy by exploiting the tax arbitrage (i.e., the possibility of deciding between two income categorizations). Thus, in a tax context, shares are used merely as a means of labor income distribution. If capital and labor incomes had been taxed at equal rates, a shareholding partner would be indifferent whether the profit for the year were to be distributed as dividend (capital gain) or salary (labor income). Hence, the value of shares, also for shareholding partners, would be the pre-emption price discounted to the present value, and the capital investment deducted. If this investment and the pre-emption price come to the same sum, the return of shares will thus be negative.

In the case under consideration here-pwc-it is also possible to be a partner with a partner's full rights, without being a shareholder (pwc's plea to the Appeals Court 28

18 See also: Statens Offentliga Utredningar [SOU] 2016:75, Översyn av skattereglerna för delägare i fåmansföretag [government report series] (Swed), 146-55. 
Table 2: Value estimates for shareholding partners and non-shareholding partners.

\begin{tabular}{lcccc}
\hline & $\begin{array}{c}\text { 1) Shareholding } \\
\text { partner }\end{array}$ & $\begin{array}{c}\text { 2) Non-shareholding } \\
\text { partner }\end{array}$ & $\begin{array}{c}\text { 1)-2), i.e., the value of } \\
\text { the share }\end{array}$ & $\begin{array}{c}\text { Shareholding } \\
\text { non-partner }\end{array}$ \\
\hline Year 1 & 62.40 & 34.35 & 28.05 & 0.00 \\
Year 2 & 62.40 & 34.35 & 28.05 & 0.00 \\
Year 3 & 62.40 & 34.35 & 28.05 & 0.00 \\
Year 4 & 62.40 & 34.35 & 28.05 & 0.00 \\
Year 5 & 62.40 & 34.35 & 28.05 & 0.00 \\
Value & $\mathbf{2 3 6 . 5 5}$ & $\mathbf{1 3 0 . 2 2}$ & $\mathbf{1 0 6 , 3 3}$ & $\mathbf{0 . 0 0}$ \\
\hline
\end{tabular}

February 2014). Such a partner without shares is entitled to the same portion of the profits as a shareholding partner. Therefore, a strong supporting argument in the pwc case is that a partner without co-ownership does not have the possibility of income shifting. Instead, the full income of that partner is taxed as labor income.

The Swedish tax system is founded on the principle that the same taxes ought to be imposed on all types of labor income, regardless of the form this income takes. ${ }^{19}$ The value of income in forms other than cash is determined by its market value, which means the local price paid for the good or service. ${ }^{20}$ In accordance with this principle, an individual who is able to purchase a good below market price is liable to pay a benefit tax on the difference between the price paid and the market price. This applies, for example, to the employees who are offered the opportunity to buy shares in their company at below-market price. Against this background, the Tax Agency argued that the market value of the partners' shares in pwc that yielded annual dividends of about 15,000 SEK was higher than the amount the partners had originally paid for them, which was 10 SEK. The Tax Agency estimated the value of the partners' shares at 35,000 SEK, so that for every share acquired by a partner, 34,990 SEK was subject to taxation as a fringe benefit. According to the Tax Agency, an outside investor-a non-partner-would be willing to pay more than 10 SEK for the opportunity to enjoy the gains awarded to partners. Implicit in this reasoning is the assumption that it is the share that yields this return. But according to pwc, this assumption is incorrect. It is in virtue of being partners rather than shareholders that entitled the employees to a portion of the company's annual surplus. The point is made clearly

19 Regeringens Proposition 1989/90:110 om reformerad inkomstsoch företagsbeskattning [government bill] (Swed), 314; Statens Offentliga Utredningar 1994:98, Beskattning av förmåner [government report series] (Swed).

20 Regeringens Proposition 1989/90:110 om reformerad inkomstsoch företagsbeskattning [government bill] (Swed), 321. in the support pwc submitted for its case in the Appeals Court: "A partner who does not hold shares has the same right to share in the profits as does a shareholding partner. [...] The only value of the shares for a consultant working in the company is the value of the tax arbitrage" ( $p$. 3). Rather, the shares are used as a mechanism by which the annual profit is distributed to partners.

The following example shows how values are calculated for shareholding and non-shareholding partners. Like the previous example, this one is based on an income of 100 SEK, a 55\% marginal income tax on work, a 20 percent tax on capital income, a 31 percent payroll tax, and a corporate tax of 22 percent. We assume that the partnership lasts for five years, that the individual joins at age 55 and retires with emption at age 60 . The discount rate, 10 percent, were chosen for purposes of exemplifying the principles at work and have not been derived either theoretically or empirically.

Columns 1 and 2, in Table 2, show the disposable incomes of a shareholding partner and a non-shareholding partner, respectively, and the present value of that income. Column 3 shows the difference in disposable income between shareholding and non-shareholding partners. The value of 106 SEK is the present value of this difference, and corresponds to the value of the tax arbitrage as well. For a non-shareholding partner, the value of shares is zero. For a shareholding partner, the entire worth of holding shares is due to the more favorable taxation. At least when the principle of naked-in-naked-out is applied, it is obvious that the share's value consists entirely of the value of tax advantage permitted-even encouraged-by the law: that of reporting what is obviously income from work as income from capital, subject to more favorable tax rates. For a nonpartner, the value of any shares held would be nil, because that shareholder is not entitled to any of the company's returns. 


\subsubsection{Is the value of the tax arbitrage a taxable benefit?}

As demonstrated in the preceding section, partners' shares have no value for the partner other than the tax arbitragethe possibility of choosing whether a certain income is to be taxed as income from labor or from capital. Yet the tax arbitrage should not be regarded as a taxable benefit. First, all close company owners currently enjoy that same possibility. Subjecting this possibility to a tax benefit would, in effect, cancel out the 3:12 regulation and make it disadvantageous to run a business, because all profits would have to be reported as benefits, taxable as labor income. This is not how the rules on close companies were intended to function. Second, treating a lower tax rate on a certain type of income as a benefit, subject to taxation runs counter to a basic principle of the dual income tax system, whereby income from work and income from capital are taxed separately. The benefit tax would subvert this cornerstone of the system and may have great, unpredictable effects on policy.

The value of a partners' share, which consists of the difference in taxation between labor income and capital income, cannot then be considered a taxable benefit. Because the sole value of these shares is the tax arbitrage, it is not possible to impose a benefit tax on them. In conclusion, the fact that the value of these shares consists of the possibility of tax arbitrage, and the fact that the tax arbitrage cannot possibly be considered a taxable benefit, means that cases like the one the Tax Agency pursued against pwc are doomed.

\section{Concluding remarks}

Legitimacy is crucial to the viability of a tax system in the long term, and thereby crucial to the economy. Both the law and adherence to the law is a matter for legitimacy. This means that the Tax Agency's interpretation of the law and its ability to pursue legal action according to its interpretation are significant parts of the tax system's legitimacy.

The legislator faces the challenge of making the legislation as efficient as possible without sacrificing legitimacy. Tax law that is generous toward one group tends to be seen as illegitimate by other taxpayers. On the other hand, entrepreneurs will regard legislation as illegitimate if it is too stifling. In the tax law pertaining to business policy, it is critical to find a balance whereby the law is regarded as legitimate both by those touched by the law and those not touched by it. We also maintain that income tax has a symbolic importance, as it is imposed on all members of a society. Income tax legislation is a powerful tool to demonstrate initiatives in response to highly charged political questions.

This article has shown that the incentive for taking initiatives that are visible to the public sometimes comes at the expense of the quality of laws and their supervision. In 2006, rules were introduced enabling lucrative income shifting using shares acquired on a naked-in-naked-out basis. Four years later, at the end of 2010, a question was raised: Are the tax benefits reasonable as conferred on the partners of accounting and consulting firms by this type of share? Consequently, the Minister of Finance publicly condemned such arrangements in 2013, and introduced a new law to prevent this type of tax planning. The Tax Agency, the supervisory authority of the Ministry of Finance, wanting to demonstrate initiative by publicly challenging the interpretation of the law on which these arrangements were based, took pwc to court.

Both these interventions, which sought to safeguard legitimacy, turned out to be major failures. The new legislation was condemned as inadequate even before it was enforced, and the criticism has only increased. Thus, a proposal was made through the 3:12 investigation that the previous legislation be scrapped and replaced by 2018 . Harsh criticism from lobbyists and aggressive rhetoric from political antagonists forced the government to withdraw its suggested legislation, however, exposing the legislature as genuinely incapable of dealing with the longstanding issue of legitimacy among tax-planning partners, as represented by pwc and other partner-owned corporations engaged in using shares acquired on a naked-innaked-out basis.

The Tax Agency pursued a trial in the limelight without any prospect of victory. Media reports of the trial testify to the amount of prestige the Tax Agency invested in it. This is also apparent from the way the trial was presented on the Tax Agency website. Despite its defeat in the Appeals Court, the Tax Agency referred to the use of shares acquired on a naked-in-naked-out basis in accounting firms as "tax arrangements", condemning them as wrongful and vowing to question them in the future. This presentation of the matter prompted the Swedish Association of Lawyers, the industry association of accounting consultants, accountants, and advisers to report the Tax Agency to the Parliamentary Ombudsman (Sveriges Advokatsamfund and FAR 2016).

The efforts of the legislator and supervisory authority notwithstanding, it is still possible to engage in income shifting with shares acquired on a naked-in-naked-out basis in partnership firms. No new legislation can be ex- 
pected in the near future. Furthermore, the legislator's and Tax Agency's efforts do not seem to have improved the legitimacy of the tax law, but rather to have decreased public trust. The goal of this article is to discuss the legitimacy of the law against the background of the legislator's and supervisory authority's actions. The legitimacy of the tax system is contingent upon both the quality of the legislation and the supervisory authority's ability to implement it. Using legislation opportunistically for symbolic demonstrations of one's good intentions or one's alignment with populist sentiment will lead to overall lower legitimacy if done at the expense of legislative quality. The legitimacy of the tax system can only be further decreased if the supervisory authority allows its actions to become instruments for political rhetoric.

\section{References}

Alstadsæter, Annette, and Jacob, Martin, Report to the Expert Group on Public Economics: Income Shifting in Sweden: An empirical evaluation of the 3:12-rules, 2012a.

Alstadsæter, Annette, and Jacob, Martin, 3:12-reglerna har blivit för generösa och används för skatteplanering, Ekonomisk Debatt, 2012b, pp. 5-12.

Alstadsæter, Annette, Jacob, Martin, and Vejsiu, Altin, Report to the Expert Group on Public Economics (ESO): 3:12-Corporations in Sweden: The Effects of the 2006 Tax Reform on Investments, Job Creation and Business Start-ups, $2014 \mathrm{a}$.

Alstadsæter, Annette, Jacob, Martin, and Vejsiu, Altin, Gynnar 3:12 reglerna värdeskapande eller skatteplanering? Ekonomisk Debatt, 2014b, pp. 66-74.

Arnold, Jens N. et al., Tax Policy for Economic Recovery and Growth, The Economic Journal, 121 (February), 2011, pp. F59-F80.

Avi-Yonah, Reuven S., The Three Goals of Taxation, Tax Law Review, 2006, pp. 1-28.

Bankman, Joseph, and Weisbach, David A., The Superiority of an Ideal Consumption Tax over an Ideal Income Tax, Stanford Law Review, 2006, pp. 1413-1456.

Bjuggren, Per-Olof and Johansson, Dan, Svar till Edin och Lodin angående 3:12-reglerna, Ekonomisk Debatt, 2008, pp. 57-59.

Bursell, Jacob, Skatteverket: "Vi vill att de hör av sig", Svenska Dagbladet, Stockholm, December 15, 2010a.

Bursell, Jacob, Revisorer slipper skatt på rea-aktier, Svenska Dagbladet, Stockholm, December 15, 2010b.

Caldéron Carrero, José Manuel, and Quintas Seara, Alberto, The Concept of 'Aggressive Tax Planning' Launched by the OECD and the EU Commission in the BEPS Era: Redefining the Border between Legitimate and Illegitimate Tax Planning, INTERTAX, 2016, pp. 206-226.

Cooper, Graeme S., Challenges and Choices - the Rule of Law and Anti-Avoidance Rules, in Cooper Graeme S. (ed) Tax Avoidance and the Rule of Law, IBFD Publication, 1997, pp. 13-50.

Dourado, Ana Paula, Aggressive Tax Planning in EU Law and in the light of BEPS: The EC Recommendation on Aggressive Tax Planning and BEPS Actions 2 and 6, INTERTAX, 2015, pp. 42-57.
Edin, Per-Olof, Hansson, Ingmar and Lodin, Sven-Olof, Report from the Ministry of Finance: Reformerad ägarbeskattning - effektivetet, prevention, legitimitet, 2005.

Edin, Per-Olof, and Lodin, Sven-Olof, En analys av en felaktig analys av 3:12-reglerna, Ekonomisk Debatt, 2008, pp. 54-56.

Ericson, Peter, and Fall, Johan, 3:12-reglerna i allsidig(are) belysning. Replik till Alstadsæter och Jacob, Ekonomisk Debatt, 2013, pp. 3943.

Fall, Johan, and Ericson, Peter, Några ekonomiska aspekter på 3:12reglernas utveckling, Skattenytt, 2013, pp. 842-852.

Freedman, Judith, The Tax Avoidance Culture: Who is Responsible? Governmental Influences and Corporate Social Responsibility, Current legal problems, 2006, pp. 359-390.

Gribnau, Hans, Corporate Social Responsibility and Tax Planning: Not by Rules Alone, Social and Legal Studies, 2015, pp. 225-250.

Hansson, Åsa, Tax Policy and Entrepreneurship: Empirical Evidence from Sweden, Small Business Economics, 2010, pp. 495-513.

Hansson, Åsa, Så får vi ett effektivt skattesystem, in Bergstrand, Mats (ed), En skattereform för 2000-talet, pmj, 2014, pp. 53-71.

Hedelius, Patricia, Guldregn över revisorer, Svenska Dagbladet, Stockholm, September 20, 2013.

Hellekant, Johan, and Hugo, Katarina, Stort missnöje med Borgs “panikåtgärd”, Svenska Dagbladet, Stockholm May 31, 2013.

Hemels, Sigrid, Fairness and Taxation in a Globalized World (February 26, 2015). Available at SSRN: https://ssrn.com/abstract $=2570750$ or http://dx.doi.org/10.2139/ssrn.2570750.

Henrekson, Magnus, Taxation of Swedish Firm Owners: The Great Reversal from the 1970 s to the 2010s. Nordic Tax Journal, 1(1), 2017, pp. 26-46. doi:10.1515/ntaxj-2017-0002

Jagers, Sverker C., and Hammar, Henrik, Environmental taxation for good and for bad: the efficiency and legitimacy of Sweden's carbon taxes, Environmental Politics, 2009, pp. 218-237.

Larsson, Peter, and Sävenstrand, Joakim, Nya 3:12-regler blir stoppregler mot tillväxt, Skattenytt, 2013, pp. 562-573.

Lodin, Sven-Olof, Några kvalitetskrav på god skattelagstiftning, Skattenytt, 2007, pp. 477-490.

Lodin, Sven-Olof, Professorn som blev näringslivstorped, Min tid i skattepolitiken, Ekerlids förlag, 2009.

Lodin, Sven-Olof, Lagändring krävs mot revisorernas skattekryphål, Svenska Dagbladet, Stockholm, January 11, 2011.

Lodin, Sven-Olof, 3:12-reglerna - följetong utan slut, in Mats Bergstrand (ed), En skattereform för 2000-talet, pmj, 2014, pp. 161-189.

Lodin, Sven-Olof, Särskilt yttrande av sakkunnige Sven-Olof Lodin, in Statens Offentliga Utredningar 2016:75, Översyn av skattereglerna för delägare i fåmansföretag [government report series] (Swed), pp. 467-474.

Murphy, Kristina, Regulating more effectively: the relationship between procedural justice, legitimacy and tax non-compliance, Journal of Law and Society, 2005, pp. 562-589.

Murphy, Liam, and Nagel, Thomas, The Myth of Ownership, Taxes and Justice, Oxford University Press, 2002.

Neurath, Caroline, and Bursell, Jacob, Lägre skatter för topprevisorer, Svenska Dagbladet, Stockholm, November 20, 2010.

Norrman, Erik, och Virin, Niclas, Slopad bolagsskatt - analys och konsekvenser, Norstedts Juridik, 2007.

Panayi, Christiana HJI, “Is Aggressive Tax Planning Socially Irresponsible?”, INTERTAX, 2015, pp. 544-558.

Soerensen, Peter Birch, Report to the Expert Group on Public Economics (ESO) 2010:4 Swedish Tax Policy: Recent Trends and Future 
Challenges, 2010a.

Sorensen, Peter Birch, Dual Income Taxes: A Nordic Tax System, in Claus, Iris et al. (eds), Tax Reforms in Open Economies, Edward Elgar, 2010b, pp. 78-108.

Stenberg, Ewa, Regeringen ändrar 3:12-reglerna igen, Dagens Nyheter, Stockholm, September 12, 2013.

Storey, David J., Understanding the Small Business Sector, International Thomson Business Press, 1994.

Sveriges Advokatsamfund, R-2013/0608 Remissyttrande över promemorian Vissa skattefrågor inför budgetpropositionen för 2014, Stockholm, May 6, 2013.

Sveriges Advokatsamfund, and FAR, Anmälan av Skatteverket i fråga om publicering av felaktig information på verkets webbplats och innehållet i en skrivelse från verket till Advokatsamfundet och FAR, Stockholm March 23, 2016.
Tjernberg, Mats, Förslaget till förändrade fåmansföretagsregler från 2014, Skattenytt, 2013, pp. 750-756.

Tjernberg, Mats, Synpunkter på översynen av fördelningsreglerna i 57 kap. IL, Skattenytt, 2017, pp. 17-32.

Tyler, Tom R., Why People Obey the Law, Yale University Press, 1990. Zachrisson Winberg, Johan, Revisorer tjänar miljoner genom skatteplanering, svt NYHETER, May 19, 2012, <http://www.svt.se/nyheter/inrikes/sveriges-framsta-revisorertjanar-miljoner-genom-skatteplanering $>$ accessed 6 January 2017.

Öberg, Ann, Avskaffad värnskatt lönsam för alla, in Bergstrand, Mats (ed), En skattereform för 2000-talet, pmj, 2014, pp. 101-113. 